\title{
Novel nitrogen-fixing acetic acid bacteria, Gluconacetobacter johannae sp. nov. and Gluconacetobacter azotocaptans sp. nov., associated with coffee plants
}

1 Programa de Ecología Molecular y Microbiana, Centro de Investigación sobre Fijación de Nitrógeno, Universidad Nacional Autónoma de México, Apdo Postal 565-A, Cuernavaca, Mor., Mexico

2 Centro de Investigaciones Microbiológicas, Instituto de Ciencias, Benemérita Universidad Autónoma de Puebla, Apdo Postal 1622, Puebla, Pue., Mexico

\author{
Luis E. Fuentes-Ramírez, ${ }^{1 \dagger}$ Rocío Bustillos-Cristales, ${ }^{1}$ \\ Armando Tapia-Hernández, ${ }^{2}$ Teresita Jiménez-Salgado, ${ }^{2}$ \\ En Tao Wang, ${ }^{1}$ Esperanza Martínez-Romero' ${ }^{1}$ \\ and Jesús Caballero-Mellado'
}

Author for correspondence: Jesús Caballero-Mellado. Tel: +52 73291703. Fax : +5 5273175581 .
e-mail: jesuscab@cifn.unam.mx

Diazotrophic bacteria were isolated, in two different years, from the rhizosphere and rhizoplane of coffee (Coffea arabica L.) plants cultivated in Mexico; they were designated as type DOR and type SAd isolates. They showed characteristics of the family Acetobacteraceae, having some features in common with Gluconacetobacter (formerly Acetobacter) diazotrophicus, the only known $\mathrm{N}_{\mathbf{2}}$-fixing species of the acetic acid bacteria, but they differed from this species with regard to several characteristics. Type DOR isolates can be differentiated phenotypically from type SAd isolates. Type DOR isolates and type SAd isolates can both be differentiated from Gluconacetobacter diazotrophicus by their growth features on culture media, their use of amino acids as nitrogen sources and their carbon-source usage. These results, together with the electrophoretic mobility patterns of metabolic enzymes and amplified rDNA restriction analysis, suggested that the type DOR and type SAd isolates represent two novel $\mathbf{N}_{2}$-fixing species. Comparative analysis of the $16 \mathrm{~S}$ rRNA sequences revealed that strains CFN-Cf55' (type DOR isolate) and CFNCa54' (type SAd isolate) were closer to Gluconacetobacter diazotrophicus (both strains had sequence similarities of $98.3 \%$ ) than to Gluconacetobacter liquefaciens, Gluconacetobacter sacchari (similarities $<98 \%$ ) or any other acetobacteria. Strain CFN-Cf55 ${ }^{\top}$ exhibited low levels of DNA-DNA reassociation with type SAd isolates (mean $42 \%$ ) and strain CFN-Ca54' exhibited mean DNA-DNA reassociation of $39.5 \%$ with type DOR isolates. Strains CFN-Cf55 ${ }^{\top}$ and CFN-Ca54 ${ }^{\top}$ exhibited very low DNA reassociation levels, 7-21\%, with other closely related acetobacterial species. On the basis of these results, two novel $\mathrm{N}_{2}$-fixing species are proposed for the family Acetobacteraceae, Gluconacetobacter johannae sp. nov. (for the type DOR isolates), with strain CFN-Cf55 ${ }^{\top}$ ( $={\text { ATCC } 700987^{\top}=\text { DSM 13595 }}^{\top}$ ) as the type strain, and Gluconacetobacter azotocaptans sp. nov. (for the type SAd isolates), with

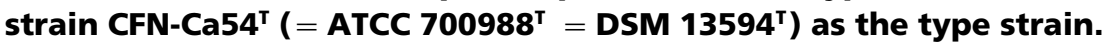

Keywords: Gluconacetobacter johannae sp. nov., Gluconacetobacter azotocaptans sp. nov., acetic acid bacteria, nitrogen fixation, coffee plants

† Present address: Centro de Investigaciones Microbiológicas, Instituto de Ciencias, Benemérita Universidad Autónoma de Puebla, Puebla, Mexico. Abbreviations: ARDRA, amplified rDNA restriction analysis; MLEE, multilocus enzyme electrophoresis.

The GenBank accession numbers for the $16 \mathrm{~S}$ rDNA sequences of strains CFN-Cf55 ${ }^{\top}$ and CFN-Ca54 $4^{\top}$ are AF111841 and AF192761, respectively. 


\section{INTRODUCTION}

Bacteria of the family Acetobacteraceae are characterized phenotypically by their ability to grow at low $\mathrm{pH}$ and by their ability to oxidize ethanol to acetic acid (De Ley et al., 1984a; Swings, 1992). This family has been divided historically into the genera Acetobacter and Gluconobacter (De Ley et al., 1984a; Swings, 1992). However, the classification of the acetic acid bacteria group has been subject to controversy. For instance, the transfer of the methylotrophic species Acetobacter methanolicus to a new genus, Acidomonas, has been proposed (Urakami et al., 1989) and is supported by $5 \mathrm{~S}$ rRNA sequence data (Bulygina et al., 1992), but the creation of this new genus has been criticized and was therefore not recognized (Sievers $e t$ al., 1994; Swings, 1992). Similarly, the establishment of the subgenus Gluconoacetobacter (Yamada \& Kondo, 1984) has been questioned (Swings, 1992). More recently, Yamada et al. (1997) proposed the division of the acetic acid bacteria into four genera, Acetobacter, Gluconobacter, Gluconoacetobacter and Acidomonas, on the basis of an analysis of partial $16 \mathrm{~S}$ rRNA sequences. In that proposal, only the species Acetobacter aceti and Acetobacter pasteurianus were retained in the genus Acetobacter, whilst the species Acetobacter diazotrophicus, Acetobacter europaeus, Acetobacter hansenii, Acetobacter liquefaciens and Acetobacter xylinus were transferred to the genus Gluconoacetobacter, which has subsequently been corrected to Gluconacetobacter (Yamada et al., 1998). In addition to the species referred to in the study by Yamada et al. (1997), two further species, Acetobacter oboediens and Acetobacter pomorum, have been described (Sokollek et al., 1998). However, Acetobacter oboediens, together with Acetobacter intermedius, has been reassigned to the genus Gluconacetobacter (Franke et al., 1999; Yamada, 2000). More recently, Gluconacetobacter sacchari, a novel species of acetic acid bacterium, has been described (Franke et al., 1999).

Gluconacetobacter (formerly Acetobacter) diazotrophicus, an endophytic bacterium (Cavalcante \& Döbereiner, 1988; Fuentes-Ramírez et al., 1993), is the only known $\mathrm{N}_{2}$-fixing species belonging to the acetic acid bacteria (Gillis et al., 1989) and is suggested to be a nitrogen contributor for sugar cane crops (Boddey et $a l .$, 1991). For this reason, therefore, the search for this species has been extended to other plants. Our search for $\mathrm{N}_{2}$-fixing bacteria associated with coffee plants led to the isolation of Gluconacetobacter diazotrophicus (Jiménez-Salgado et al., 1997). In addition, other acetic-acid-producing, diazotrophic bacteria were recovered from the rhizospheres of coffee plants. These diazotrophs, referred to in our previous study as type DOR, SAd, NAP and APL isolates, shared features with the genus Gluconacetobacter but differed from Gluconacetobacter diazotrophicus with respect to morphological and biochemical traits, as well as genetic and molecular features.
In this study, we present an extended taxonomic analysis of type DOR and type SAd isolates, including new isolates recovered from the rhizospheres and rhizoplanes of coffee plants. We present evidence that indicates that these isolates represent two novel $\mathrm{N}_{2}$ fixing species within the genus Gluconacetobacter. We propose the names Gluconacetobacter johannae sp. nov. for the type DOR isolates and Gluconacetobacter azotocaptans $\mathrm{sp}$. nov. for the type SAd isolates.

\section{METHODS}

Isolation and reference strains. Rhizosphere soil around the root and root samples from coffee plants (Coffea arabica L. var. Caturra, collected in Motozintla, Chiapas State, Mexico) were treated as described previously (JiménezSalgado et al., 1997) and were inoculated into vials containing $5 \mathrm{ml} \mathrm{N}$-free semi-solid LGI medium (Cavalcante \& Döbereiner, 1988). Vials were incubated at $30^{\circ} \mathrm{C}$ for $5 \mathrm{~d}$; thereafter, vials were replicated under the same conditions and assayed for acetylene-reduction activity as described previously (Mascarúa-Esparza et al., 1988). $\mathrm{N}_{2}$-fixing type DOR and SAd isolates were recovered as described previously (Jiménez-Salgado et al., 1997); $\mathrm{N}_{2}$-fixing type DOR and SAd isolates and strains representative of the different species of the family Acetobacteraceae used in this study are shown in Table 1.

Phenotypic characterization. Strains were grown at $29{ }^{\circ} \mathrm{C}$ unless otherwise indicated. An inoculum was prepared by growing type DOR or SAd isolates and Gluconacetobacter diazotrophicus strains for $12 \mathrm{~h}$ in SYP medium (CaballeroMellado \& Martínez-Romero, 1994) modified by increasing the amount of yeast extract to $0 \cdot 3 \%(\mathrm{w} / \mathrm{v})$. Other acetobacteria species were grown in MESMA liquid medium (Fuentes-Ramírez et al., 1999). The cultures were centrifuged twice and resuspended in $10 \mathrm{mM} \mathrm{MgSO}_{4}$. Each culture was streaked on solid media to determine phenotypic characteristics. Four replicates were used for each characteristic examined; growth was recorded after $5 \mathrm{~d}$ of incubation. Colony morphology was examined on LGI (Cavalcante \& Döbereiner, 1988) agar plates supplemented with $0.005 \%$ yeast extract and on potato agar (Cavalcante \& Döbereiner, 1988 ) containing 5,10 or $15 \%(\mathrm{w} / \mathrm{v})$ cane sugar. Compounds used as sole carbon sources were tested in the presence and absence of growth factors from yeast extract $(0.005 \%)$, using LGI medium supplemented with $0 \cdot 1 \% \mathrm{NH}_{4} \mathrm{Cl}$, and with cane sugar replaced by individual filter-sterilized $(0.22 \mu \mathrm{m}$ pore) carbon substrates $(0.5 \%)$. Acetic acid and citric acid were also tested at $0 \cdot 1 \%$. Butanol, ethanol and methanol were tested at 0.1 and $0.5 \%(\mathrm{v} / \mathrm{v})$. Sucrose was used as a positive control; the negative control did not contain a carbon substrate. When amino acids were tested as sole nitrogen sources, the LGI medium was modified by omitting cane sugar and adding sorbitol at a final concentration of $0.5 \%(\mathrm{w} / \mathrm{v})$. Modified LGI medium containing $\mathrm{NH}_{4} \mathrm{Cl}(0 \cdot 1 \%, \mathrm{w} / \mathrm{v})$ was used as a positive control; the negative control lacked a nitrogen source. The same LGI basal medium (without cane sugar) was used to test L-amino acids as carbon and nitrogen sources. LGI basal media containing sucrose $(0 \cdot 5 \%)$ and $\mathrm{NH}_{4} \mathrm{Cl}(0 \cdot 1 \%)$ or lacking both carbon and nitrogen sources were used as positive and negative controls. Filter-sterilized $(0.22 \mu \mathrm{m}$ pore $)$ L-amino acids were added (final concentration $0.1 \%$ ) in both assays described above. Unless stated otherwise, LGI culture medium was adjusted with $\mathrm{HCl}$ to a final $\mathrm{pH}$ of 5.5 for the 
Table 1. Representative strains of novel $\mathrm{N}_{2}$-fixing acetobacteria species associated with coffee plants and strains of related species used in this study

\begin{tabular}{|c|c|c|}
\hline Strain & Source of isolate & Reference/source \\
\hline \multicolumn{3}{|l|}{ Type DOR isolates } \\
\hline Gluconacetobacter johannae CFN-Cf55 $5^{\mathrm{T}}$ & Rhizosphere & Jiménez-Salgado et al. (1997) \\
\hline Gluconacetobacter johannae UAP-Cf57 & Rhizosphere & Jiménez-Salgado et al. (1997) \\
\hline Gluconacetobacter johannae CFN-Cf75 & Rhizosphere & This study \\
\hline Gluconacetobacter johannae UAP-Cf76 & Rhizoplane & This study \\
\hline \multicolumn{3}{|l|}{ Type SAd isolates } \\
\hline Gluconacetobacter azotocaptans $\mathrm{CFN}-\mathrm{Ca} 54^{\mathrm{T} *}$ & Rhizosphere & Jiménez-Salgado et al. (1997) \\
\hline Gluconacetobacter azotocaptans UAP-Ca97 & Rhizosphere & This study \\
\hline Gluconacetobacter azotocaptans UAP-Ca99 & Rhizoplane & This study \\
\hline Gluconacetobacter diazotrophicus PAl $5^{\mathrm{T}}$ & Sugar cane & Cavalcante \& Döbereiner (1988) \\
\hline Gluconacetobacter diazotrophicus UAP-5560 & Sugar cane & Fuentes-Ramírez et al. (1993) \\
\hline Gluconacetobacter diazotrophicus UAP-Cf05 & Coffee & Jiménez-Salgado et al. (1997) \\
\hline Acetobacter aceti ATCC $15973^{\mathrm{T}}$ & - & ATCC \\
\hline Acetobacter pasteurianus ATCC $33445^{\mathrm{T}}$ & - & ATCC \\
\hline Gluconacetobacter hansenii ATCC $35959^{\mathrm{T}}$ & - & ATCC \\
\hline Gluconacetobacter liquefaciens ATCC $14835^{\mathrm{T}}$ & - & ATCC \\
\hline Gluconobacter oxydans ATCC $19357^{\mathrm{T}}$ & - & ATCC \\
\hline
\end{tabular}

* This strain was formerly designated CFN-Cf54 (Jiménez-Salgado et al., 1997).

tests described above, and production of acid was recorded. In LGI medium, bromcresol green $(0 \cdot 0025 \%)$ was used as the $\mathrm{pH}$ indicator instead of bromothymol blue. Additional tests included the production of water-soluble brown pigments, the oxidation of ethanol to acetic acid and the oxidation of acetate or lactate to $\mathrm{CO}_{2}$ and water on GYC medium (De Ley et al., 1984b). Growth at 29 and $37^{\circ} \mathrm{C}$ at various $\mathrm{pH}$ values and tolerance of $\mathrm{NaCl}$ at up to $1.5 \%$ $(\mathrm{w} / \mathrm{v})$ were determined in LGI liquid medium supplemented with $0.005 \%$ yeast extract.

Multilocus enzyme electrophoresis (MLEE). Cell extracts for MLEE assays were prepared as described previously (Caballero-Mellado \& Martínez-Romero, 1994). Starch gel electrophoresis and the selective staining of indophenol oxidase, lysine dehydrogenase, leucine dehydrogenase, xanthine dehydrogenase, alcohol dehydrogenase, isocitrate dehydrogenase, glucose-6-phosphate dehydrogenase, hexokinase, esterases and an unidentified dehydrogenase were done by using methods described previously (Selander et al., 1986). These enzymes were analysed under the conditions described previously (Caballero-Mellado et al., 1995). Distinctive combinations of alleles for the 10 enzyme loci were designated as different electrophoretic types (Selander et al., 1986). The dendrogram illustrating the relatedness among strains was obtained from the programs ETDIV and ETCLUS from T. S. Whittam, kindly provided by B. D. Eardly (Pennsylvania State University). Gluconacetobacter diazotrophicus strains PAl 5 ${ }^{\mathrm{T}}$, UAP 5560 and UAP-Cf 05 and the type strains of Gluconacetobacter hansenii, Gluconacetobacter liquefaciens, Acetobacter aceti and Acetobacter pasteurianus were included as references in MLEE assays.

DNA isolation, RFLP analysis of 16S rRNA genes and DNA-DNA reassociation analysis. Cultures were grown in SYP or MESMA liquid media for $16 \mathrm{~h}$ and centrifuged at $12000 \mathrm{~g}$ and total DNA was prepared by using a DNARNA isolation kit (USB Amersham). To distinguish the family Acetobacteraceae from other $\alpha$-Proteobacteria, hybri- dization patterns of $16 \mathrm{~S}$ rRNA genes were analysed as described previously (Jiménez-Salgado et al., 1997). Total DNA from the $\mathrm{N}_{2}$-fixing acetobacteria was restricted with $S p h \mathrm{I}$ and NcoI and Southern blots were hybridized with a $16 \mathrm{~S}$ rDNA probe. In addition, DNA was digested with EcoRI and electrophoresed in vertical $1.0 \%$ agarose gels; total DNA digests were transferred from gels to nylon filters by Southern blotting (Caballero-Mellado \& MartínezRomero, 1994). DNA relatedness was based on relative levels of reassociation to ${ }^{32} \mathrm{P}$-labelled DNA, using the rediprime DNA-labelling system (Amersham). Labelled DNAs in independent experiments were from strains CFN$\mathrm{Cf}^{5} 5^{\mathrm{T}}$ (type DOR isolate) and $\mathrm{CFN}-\mathrm{Ca} 54^{\mathrm{T}}$ (type SAd isolate). DNA-DNA reassociation was for $12 \mathrm{~h}$ at $65^{\circ} \mathrm{C}$ and the nylon filters were washed once in $2 \times \mathrm{SSC}$ at room temperature for $10 \mathrm{~min}$ and once in $1 \times \mathrm{SSC}$ for $5 \mathrm{~min}$ at $65^{\circ} \mathrm{C}$. Autoradiography was performed for $4 \mathrm{~h}$; filter lanes were cut and the radioactivity estimated with a Beckman scintillation counter. Percentage reassociation was calculated for each strain tested in relation to the homologous control.

Amplified rDNA restriction analysis (ARDRA) and nucleotide sequence of $16 \mathrm{~S}$ rRNA genes. The 16S rRNA genes from strains $\mathrm{CFN}-\mathrm{Cf} 55^{\mathrm{T}}$ and $\mathrm{CFN}-\mathrm{Ca} 54^{\mathrm{T}}$ were amplified by PCR with the primers fD1 and rD1 (Weisburg et al., 1991) using the proof-reading Pwo DNA polymerase (BoehringerRoche). The PCR conditions were an initial denaturing cycle $\left(95^{\circ} \mathrm{C}, 3 \mathrm{~min}\right), 35$ amplification cycles $\left(95^{\circ} \mathrm{C}, 1 \mathrm{~min} ; 55^{\circ} \mathrm{C}\right.$, $\left.1 \mathrm{~min} ; 72^{\circ} \mathrm{C}, 2 \mathrm{~min}\right)$ and a final elongation cycle $\left(72^{\circ} \mathrm{C}, 3\right.$ min). Approximately $400 \mathrm{ng}$ PCR-amplified 16S rRNA gene fragment (approx. $1.5 \mathrm{~kb}$ ) was restricted with $10 \mathrm{U}$ of each endonuclease (AluI, DdeI, HaeIII, HhaI, MspI, NciI, RsaI, Sau3AI and TaqI). The lengths of the restriction fragments were determined from their electrophoretic separation in $3 \%$ agarose gels and the restriction patterns from each isolate were compared. To obtain nucleotide sequences, PCR products from strains $\mathrm{CFN}-\mathrm{Cf} 55^{\mathrm{T}}$ and $\mathrm{CFN}-\mathrm{Ca} 54^{\mathrm{T}}$ 
Table 2. Comparison of the novel $\mathrm{N}_{2}$-fixing acetobacteria with Gluconacetobacter diazotrophicus

The number of strains of each species analysed is shown. Characters are scored as: + , good growth; \pm , slight growth; - , no growth. Ranges are indicated by e.g. $+/ \pm$. All taxa shown were catalase-positive and oxidase-negative and oxidized ethanol to acetic acid and acetate and lactate to $\mathrm{CO}_{2}$ and water; were positive for acetylene reduction, even with $10 \mathrm{mM}$ nitrate, and negative for nitrate reduction. All taxa shown grew on sucrose, D-glucose, L-fructose and gluconate, used L-alanine and L-aspartic acid as nitrogen sources with sorbitol as the carbon source and showed slight growth on L-leucine or L-lysine and no growth on L-glycine, L-methionine or L-threonine. None of the taxa used D-lactose, L-rhamnose, dulcitol, myo-inositol, citric acid, fumaric acid, D-glucuronic acid, DL-malic acid, starch or methanol $(0.1$ or $0.5 \%)$ as sole carbon sources or used single amino acids (L-alanine, L-aspartic acid, L-cysteine, L-glutamic acid, L-glycine, L-leucine, L-lysine, L-proline, L-methionine, L-phenylalanine, L-threonine or L-tryptophan) as sole sources of carbon and nitrogen. G., Gluconacetobacter.

\begin{tabular}{|c|c|c|c|}
\hline Characteristic & $\begin{array}{l}\text { Type DOR }(n=4) \\
\quad(G . \text { johannae })\end{array}$ & $\begin{array}{l}\text { Type SAd }(n=3) \\
(G . \text { azotocaptans) }\end{array}$ & $\begin{array}{l}\text { G. diazotrophicus } \\
\qquad(n=3)\end{array}$ \\
\hline $\begin{array}{l}\text { Dark brown colonies on potato } \\
\text { agar with } 5,10 \text { or } 15 \% \text { sugar }\end{array}$ & No & No & Yes \\
\hline \multicolumn{4}{|l|}{ Growth on:* } \\
\hline D-Galactose & + & \pm & + \\
\hline D-Xylose & + & - & $\pm /-$ \\
\hline D-Raffinose & $+/ \pm$ & - & + \\
\hline D-Arabinose & $\pm /-$ & - & + \\
\hline Melibiose & \pm & $\pm /-$ & \pm \\
\hline Maltose & $+/ \pm$ & $\pm /-$ & $\pm /-$ \\
\hline Mannose & - & - & \pm \\
\hline D-Sorbitol & $+/ \pm$ & $+/ \pm$ & + \\
\hline Glycerol & $\pm /-$ & - & + \\
\hline D-Mannitol & $\pm /-$ & - & + \\
\hline Ethanol & + & $+/ \pm$ & \pm \\
\hline Butanol & \pm & - & - \\
\hline \multicolumn{4}{|c|}{$\begin{array}{l}\text { Growth on L-amino acids in the presence } \\
\text { of sorbitol as carbon source: }\end{array}$} \\
\hline L-Cysteine & - & + & + \\
\hline L-Glutamic acid & - & + & + \\
\hline L-Proline & - & - & + \\
\hline L-Tryptophan & + & - & + \\
\hline
\end{tabular}

* Regardless of the presence or absence of growth factors from yeast extract.

were cloned initially with a PCR cloning kit (BoehringerRoche) in the pCAPs vector and subcloned in pUC19. Nucleotide sequences of the 16S rDNA genes were determined with an ALF automated sequencer (Pharmacia Biotech) using fluorescent primers for M13. The 16S rDNA sequences corresponded to positions 17-1524 of the sequence of Escherichia coli K-12 (accession no. AE000460).

ARDRA and nucleotide sequence analyses. The nucleotide sequences obtained in this study were compared with different $16 \mathrm{~S}$ rDNA sequences of acetic acid bacteria obtained from GenBank. Multiple alignment of the sequences was performed by progressive pairwise alignments with the Wisconsin package (GCG version 8), based on the method of Feng \& Doolittle (1987). Corrected evolutionary distances were calculated with the GCG version 8 using the method of Jukes \& Cantor (1969). Taxonomic tree files from ARDRA and DNA sequences were constructed with the neighbour-joining method, using CLUSTAL W (Thompson et $a l .$, 1994). The trees were bootstrapped with CLUSTAL $\mathrm{W}$ and displayed with the TREEVIEW program (Page, 1996). Over 50 16S rDNA sequences (accession numbers not shown) from acetic acid bacteria were aligned in order to search for discriminatory $S p h \mathrm{I}$ and $N c o$ I restriction sites, as described previously (Jiménez-Salgado et al., 1997).
Design of specific primers and PCR conditions. To obtain a rapid identification test for the type DOR and SAd isolates, specific primers were designed. The aligned 16S rDNA sequences from acetic acid bacteria showed conserved and variable regions. A region that did not show variability among the Acetobacteraceae species was selected for use in the design of a universal oligonucleotide. The variable regions were selected for use in the design of DOR- and SAdspecific oligonucleotides. Primers were designed with the help of the software OLIGo 4.0. PCR amplifications of $16 \mathrm{~S}$ rDNA were performed both with purified DNA and with supernatants of cells heated at $95^{\circ} \mathrm{C}$ for $8 \mathrm{~min}$ and centrifuged for $2 \mathrm{~min}$ at $12000 \mathrm{~g}$. PCRs contained $2.5 \mathrm{mM} \mathrm{MgCl}_{2}$, $20 \mathrm{nM}$ primers, $1 \mu \mathrm{M}$ dNTPs and $0.06 \mathrm{U}$ Taq polymerase $\mu \mathrm{l}^{-1}$. PCR amplifications were performed with the primer U475 and one of the specific primers, using the following protocol: $95^{\circ} \mathrm{C}$ for $3 \mathrm{~min}, 32$ cycles of $95^{\circ} \mathrm{C}$ for $1 \mathrm{~min}$, specific primer annealing temperature for $1 \mathrm{~min}$ and $72{ }^{\circ} \mathrm{C}$ for $1 \mathrm{~min}$ and finally $72^{\circ} \mathrm{C}$ for $3 \mathrm{~min}$. Amplifications with the selected primers were tested both with purified DNA and with cell extracts of the strains described in Table 1, as well as Acidomonas methanolica ATCC 43581, Gluconacetobacter xylinus ATCC 700178, Gluconobacter cerinus ATCC $19441^{\mathrm{T}}$ and Gluconobacter asaii ATCC 43781. 


\section{RESULTS}

Phenotypic analysis of novel $\mathrm{N}_{2}$-fixing acetobacterial species

Typical phenotypic characteristics of the $\mathrm{N}_{2}$-fixing type DOR and type SAd isolates were compared with phenotypic features of Gluconacetobacter diazotrophicus (Table 2). The three $\mathrm{N}_{2}$-fixing acetobacteria were Gram-negative and motile by means of peritrichous flagella (data not shown). They were capable of producing water-soluble brown pigments; however, the production of these pigments was variable among isolates of Gluconacetobacter diazotrophicus. Growth of type DOR and type SAd isolates in N-free semisolid LGI medium resulted in the formation of a yellow surface pellicle similar to that described for Gluconacetobacter diazotrophicus (Cavalcante \& Döbereiner, 1988), and isolates showed acetylenereduction activity. However, these isolates did not exhibit growth typical of Gluconacetobacter diazotrophicus on LGI agar plates. The colony morphology of type DOR isolates has been described previously (Jiménez-Salgado et al., 1997). DOR isolates in pure culture formed yellow-orange colonies, but, in contrast to those of Gluconacetobacter diazotrophicus, they were very irregular, smooth, flat colonies, 3-5 mm in diameter after $5 \mathrm{~d}$ growth. Type SAd colonies were similar to those of Gluconacetobacter diazotrophicus with regard to their orange colour, but formed round, mucous, smooth, convex colonies, $3-5 \mathrm{~mm}$ in diameter and with translucent margins. On potato agar with 5,10 or $15 \%$ cane sugar, Gluconacetobacter diazotrophicus formed very characteristic dark-brown colonies after $5 \mathrm{~d}$, as described elsewhere (Cavalcante \& Döbereiner, 1988), whereas type SAd colonies were light brown (one isolate was reddish) but turned brownish after $10 \mathrm{~d}$, and produced a brownish liquid pigment. In contrast, type DOR isolates formed only beige, or very light-brownish, colonies, even after $10 \mathrm{~d}$ incubation on potato agar plates.

Type DOR and SAd isolates differed from Gluconacetobacter diazotrophicus in their ability to utilize some substrates as sole carbon sources; regardless of the presence of growth factors from yeast extract, only a very few of the carbon substrates supported growth of the type DOR and type SAd isolates (Table 2). Growth of the type DOR and SAd isolates was slight on succinic acid. However, type DOR isolates can be differentiated from SAd isolates by their ability to grow on D-xylose, D-raffinose and $0.1 \%$ butanol. In addition, in the presence of sorbitol as the carbon source, type SAd isolates can be differentiated from the DOR isolates by their ability to utilize L-cysteine and L-glutamic acid (but not L-tryptophan) as nitrogen sources (Table 2). Type DOR isolates produced abundant acid on D-galactose, D-xylose and ethanol, but gave only slight acid production on D-raffinose, Darabinose, maltose, D-sorbitol, glycerol and butanol. Type SAd isolates, like DOR isolates, produced abundant acid on 0.1 and $0.5 \%$ ethanol, but, in

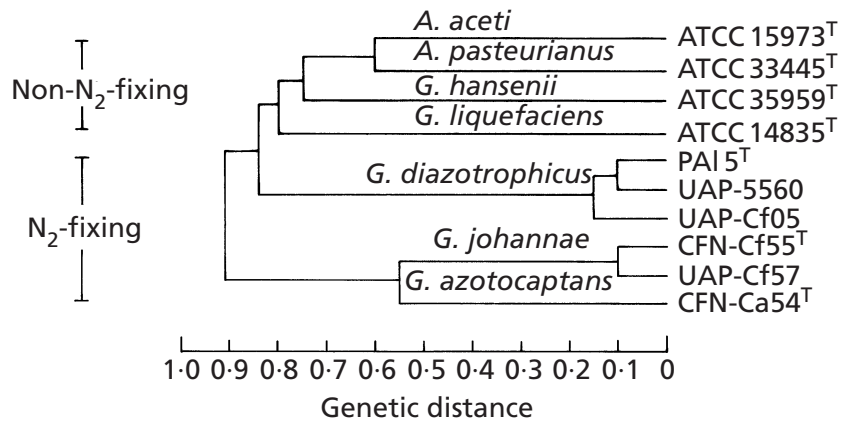

Fig. 1. Relationships among the $\mathrm{N}_{2}$-fixing type DOR (Gluconacetobacter johannae) and type SAd (Gluconacetobacter azotocaptans) isolates and reference species of Acetobacter (A.) and Gluconacetobacter (G.) determined by MLEE. The electrophoretic types of strains UAP-Cf76 and CFN-Cf75 corresponded to those of strains $\mathrm{CFN}-\mathrm{Cf} 55^{\top}$ and UAP-Cf57, respectively. The electrophoretic types of strains UAP-Ca97 and UAP-Ca99 corresponded to that of strain CFN-Ca54 ${ }^{\top}$.

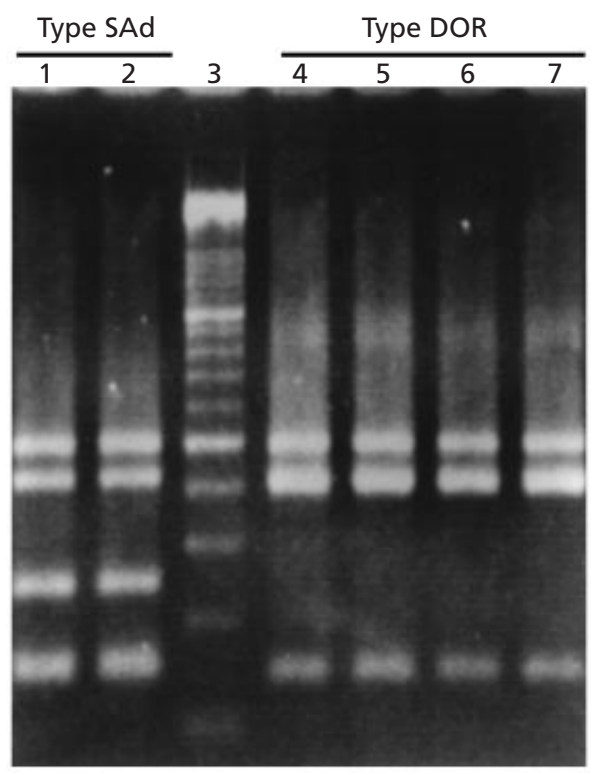

Fig. 2. ARDRA profiles of the $\mathrm{N}_{2}$-fixing type $D O R$ (Gluconacetobacter johannae) and type SAd (Gluconacetobacter azotocaptans) isolates digested with Rsal. Lanes: 1, CFN-Ca54 ${ }^{\mathrm{T}}$; 2, UAP-Ca97; 3, 100 bp molecular size marker; 4, CFN-Cf55 ${ }^{\top}$; 5, UAP-Cf57; 6, CFN-Cf75; 7, UAP-Cf76.

contrast, they showed only slight acid production when grown on D-galactose and D-sorbitol.

\section{MLEE assays}

The relationships among the $\mathrm{N}_{2}$-fixing type DOR and type SAd isolates and reference species of Acetobacter and Gluconacetobacter are illustrated by a dendrogram based on the electrophoretic mobility of metabolic enzymes (Fig. 1). The analysis revealed that the $\mathrm{N}_{2}-$ 


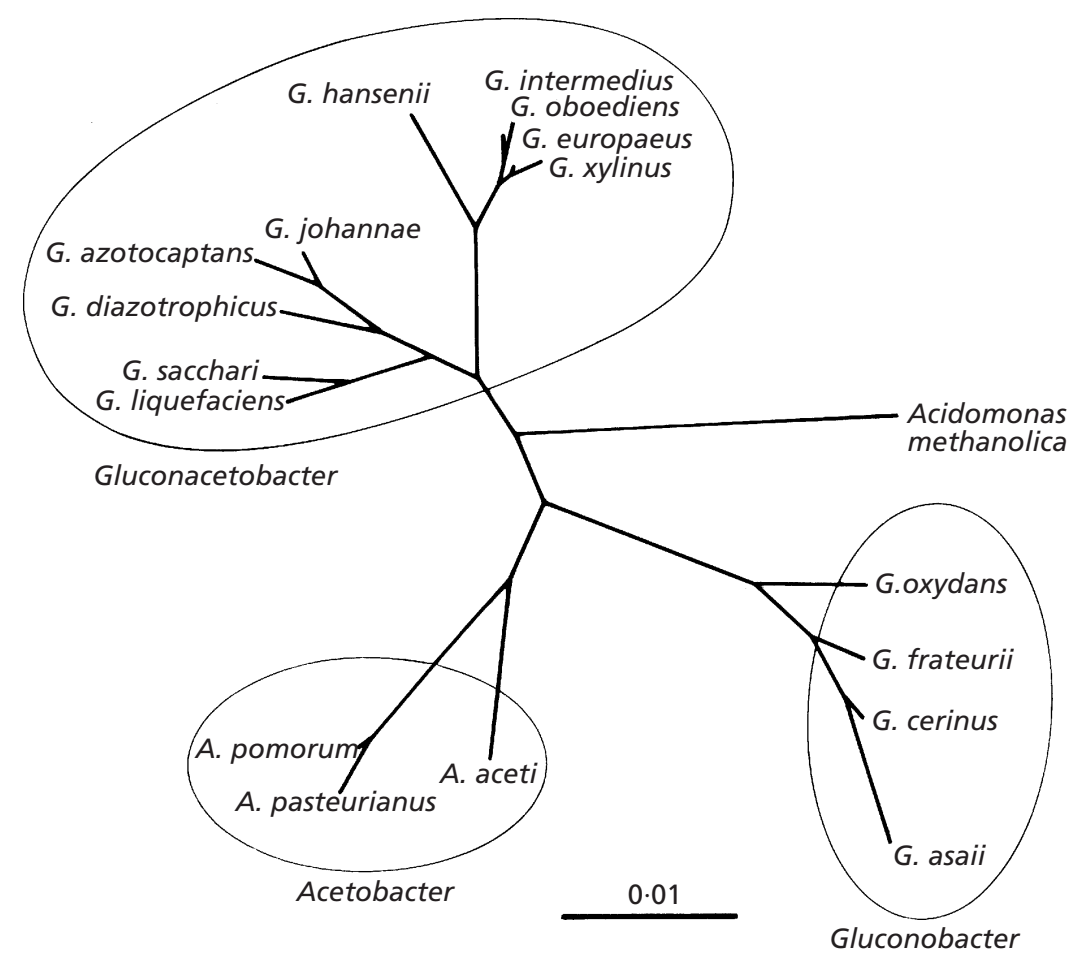

Fig. 3. Phylogenetic tree showing the relationships of the $\mathrm{N}_{2}$-fixing type DOR (Gluconacetobacter johannae) and type SAd (Gluconacetobacter azotocaptans) isolates among the Acetobacteraceae. The tree was based on 16S rRNA gene sequences from acetic acid bacteria, and represents the maximum-likelihood tree that was obtained by progressive alignment. GenBank accession numbers were X75618 (Gluconacetobacter diazotrophicus PAI $5^{\top}$ ), Z21936 (Gluconacetobacter europaeus DSM $6160^{\top}$ ), X75620 (Gluconacetobacter hansenii NCIB $\left.8746^{\top}\right)$, Y14694 (Gluconacetobacter intermedius $\mathrm{TF2}^{\top}$ ), X75617 (Gluconacetobacter liquefaciens IFO $12388^{\top}$ ), AF127407 (Gluconacetobacter sacchari SRI $1794^{\top}$ ), AJ007698 (Gluconacetobacter xylinus BPR 2001), X75619 (Gluconacetobacter xylinus NCIB $11664^{\top}$ ), AJ001631 (Gluconacetobacter oboediens LTH 2460'), X77468 (Acidomonas methanolica LMG $1668^{\top}$ ), X74066 (Acetobacter aceti $\left.\mathrm{NCIB} 8621^{\top}\right), \quad \mathrm{X} 71863$ (Acetobacter pasteurianus LMD $22.1^{\top}$ ), AJ001632 (Acetobacter pomorum LTH $2478^{\top}$ ), X80165 (Gluconobacter asaii IFO $3276^{\top}$ ), X80775 (Gluconobacter cerinus IFO $3267^{\top}$ ), X82290 (Gluconobacter frateurii IFO $3264^{\top}$ ) and X73820 (Gluconobacter oxydans DSM $3503^{\top}$ ). Bar, $1 \%$ estimated sequence divergence.

fixing type DOR and type SAd isolates formed two unique clusters, at a genetic distance of 0.560 , which diverged significantly at distances of 0.920 from the Gluconacetobacter diazotrophicus cluster as well as from the non- $\mathrm{N}_{2}$-fixing Acetobacter-Gluconacetobacter cluster.

\section{RFLPs of $16 S$ rDNA genes}

Genomic DNA from the type DOR and type SAd isolates digested with $S p h \mathrm{I}$ and $\mathrm{Nco}$ I showed $1 \cdot 3$ and $1.24 \mathrm{~kb}$ bands, respectively, when hybridized with the $16 \mathrm{~S}$ rDNA probe (data not shown). Such hybridization bands were observed previously in the Acetobacteraceae (Jiménez-Salgado et al., 1997).

\section{ARDRA analysis and nucleotide sequence of $16 \mathrm{~S}$ rRNA genes}

Type DOR, type SAd and Gluconacetobacter diazotrophicus isolates showed different restriction patterns for PCR products of $16 \mathrm{~S}$ rDNA. Patterns from AluI, DdeI, MspI, NciI and TaqI digestions of 16S rDNA differentiated type DOR and type SAd isolates from those of Gluconacetobacter diazotrophicus (data not shown). Similarly, the patterns from AluI, DdeI, Sau3AI, TaqI and RsaI digestions of 16S rDNA differentiated DOR and SAd isolates from those of Gluconacetobacter liquefaciens (data not shown). Type DOR isolates can be differentiated from type SAd strains by riboprinting only with $R s a$ I digestion (Fig.
2). The 16S rDNA sequence of Gluconacetobacter johannae (DOR isolates) shows three $R s a \mathrm{I}$ sites, giving fragments of 403, 405, 504 and $135 \mathrm{bp}$. Gluconacetobacter azotocaptans (SAd isolates) possesses four RsaI sites, generating fragments of 404, 159, 246, 504 and $134 \mathrm{bp}$. The 403 and $405 \mathrm{bp}$ fragments in Gluconacetobacter johannae and those of 159 and $134 \mathrm{bp}$ in Gluconacetobacter azotocaptans migrated together in agarose gel electrophoresis. In addition, the 16S rDNA sequences of the strains CFN-Cf55 ${ }^{\mathrm{T}}$ and $\mathrm{CFN}-\mathrm{Ca} 54^{\mathrm{T}}$ were aligned and compared with those of closely related bacteria present in GenBank. The phylogenetic tree obtained with the $16 \mathrm{~S}$ rDNA sequence data of the acetic-acid-producing bacteria is illustrated in Fig. 3 . The genus Gluconacetobacter clearly constituted a cluster separate from the clusters formed by the genera Acetobacter, Acidomonas and Gluconobacter. Two subclusters were clearly evident within the genus Gluconacetobacter: one contained only non-diazotrophic species (Gluconacetobacter europaeus, Gluconacetobacter hansenii, Gluconacetobacter xylinus, Gluconacetobacter oboediens and Gluconacetobacter intermedius) and the other included both the non-diazotrophic species Gluconacetobacter liquefaciens and Gluconacetobacter sacchari as well as Gluconacetobacter diazotrophicus and the novel $\mathrm{N}_{2}$-fixing type DOR (strain CFN-Cf55 $5^{\mathrm{T}}$ ) and type SAd (strain CFN$\mathrm{Ca} 54^{\mathrm{T}}$ ) isolates. On the basis of the $16 \mathrm{~S}$ rDNA sequence analysis, strains $\mathrm{CFN}-\mathrm{Cf} 55^{\mathrm{T}}$ and $\mathrm{CFN}$ Ca54 ${ }^{\mathrm{T}}(99 \cdot 31 \%$ similarity) were closer to Gluconacetobacter diazotrophicus PAl $5^{\mathrm{T}}$ (both strains 
Table 3. DNA-DNA hybridization levels between representative strains of the novel $\mathrm{N}_{2}$-fixing acetobacteria species and type strains of related species

\begin{tabular}{|c|c|c|}
\hline \multirow[t]{2}{*}{ Strain } & \multicolumn{2}{|c|}{ DNA relatedness (\%) with: } \\
\hline & CFN-Cf55 & CFN-Ca54 ${ }^{\mathrm{T}}$ \\
\hline Gluconacetobacter johannae $\mathrm{CFN}-\mathrm{Cf} 55^{\mathrm{T}}$ & 100 & 42 \\
\hline Gluconacetobacter johannae UAP-Cf57 & 97 & 49 \\
\hline Gluconacetobacter johannae UAP-Cf76 & 95 & 33 \\
\hline Gluconacetobacter johannae CFN-Cf75 & 79 & 34 \\
\hline Gluconacetobacter azotocaptans $\mathrm{CFN}-\mathrm{Ca} 54^{\mathrm{T}}$ & 45 & 100 \\
\hline Gluconacetobacter azotocaptans UAP-Ca97 & 50 & 79 \\
\hline Gluconacetobacter azotocaptans UAP-Ca99 & 31 & 80 \\
\hline Gluconacetobacter diazotrophicus $\mathrm{PAl} 5^{\mathrm{T}}$ & 19 & 12 \\
\hline Gluconacetobacter diazotrophicus UAP-5560 & 21 & 20 \\
\hline Gluconacetobacter liquefaciens ATCC $14835^{\mathrm{T}}$ & 21 & 18 \\
\hline Acetobacter aceti ATCC $15973^{\mathrm{T}}$ & 7 & 8 \\
\hline Gluconobacter oxydans ATCC $19357^{\mathrm{T}}$ & 7 & 7 \\
\hline
\end{tabular}

having similarities of $98.3 \%$ ) than to either Gluconacetobacter liquefaciens (similarities of 97.83 and $97.76 \%$, respectively) or Gluconacetobacter sacchari (similarities of 97.83 and $97.68 \%$, respectively).

\section{Primer sequences}

The following primers showed specific amplification of a fragment of the $16 \mathrm{~S}$ rRNA genes of type DOR and type SAd isolates: primer U475 (5'-AATGACTGGGCGTAAAG-3', universal primer); primer $\mathrm{L} 927 \mathrm{Gj}$ (5'-GAAATGAACATCTCTGCT-3', Gluconacetobacter johannae specific); primer L923Ga (5'-AATGCTCATCTCTGAACA-3', Gluconacetobacter azotocaptans specific). The annealing temperatures were $62{ }^{\circ} \mathrm{C}$ (oligonucleotide $\mathrm{L} 927 \mathrm{Gj}$ ) and $67^{\circ} \mathrm{C}$ (primer L923Ga). Under the conditions described, these primers allowed the amplification of a fragment of approximately $400 \mathrm{bp}$ from the targeted species only (results not shown).

\section{DNA relatedness}

The results of DNA-DNA reassociation experiments are shown in Table 3. Type DOR isolates constituted a homogeneous group with high levels of DNA-DNA reassociation (mean $92.75 \%$ ) with reference strain CFN-Cf55 $5^{\mathrm{T}}$. Strain CFN-Cf55 ${ }^{\mathrm{T}}$ exhibited a relatively low level of DNA-DNA reassociation with the type SAd isolates (mean $42 \%$ ). DNAs from other related acetobacterial species, including Gluconacetobacter diazotrophicus, Gluconacetobacter liquefaciens, Acetobacter aceti and Gluconobacter oxydans, exhibited very low DNA-DNA reassociation levels, ranging from 7 to $21 \%$, with total DNA from strain CFN-Cf55 $5^{\mathrm{T}}$. In addition, a homogeneous group with relatively high levels of DNA-DNA reassociation (mean $86.3 \%$ ) was found among type SAd isolates with reference strain
$\mathrm{CFN}-\mathrm{Ca} 54^{\mathrm{T}}$. The DNA relatedness of strain CFNCa $54^{\mathrm{T}}$ with type DOR isolates exhibited a mean of $39.5 \%$ and the same strain $\left(\mathrm{CFN}-\mathrm{Ca} 54^{\mathrm{T}}\right)$ exhibited less than $20 \%$ reassociation (range $7-20 \%$ ) with the other related acetobacterial species mentioned above.

\section{DISCUSSION}

It is well known that Gram-negative, rod-shaped, aerobic bacteria that oxidize ethanol to acetic acid in neutral or acid media are candidates for membership of the family Acetobacteraceae (Swings, 1992). Additionally, the family Acetobacteraceae can be distinguished from other $\alpha$-Proteobacteria by two internal $S p h$ I and NcoI restriction sites in their 16S rDNA genes, except in the case of Gluconobacter oxydans, which lacks one of the $N c o$ I restriction sites (because of a change in the base corresponding to nucleotide 110 of Gluconacetobacter diazotrophicus) (CaballeroMellado et al., 1999; Jiménez-Salgado et al., 1997). Analysis of the 16S rDNA nucleotide sequence of the majority of acetobacterial strains reported in GenBank revealed that only a few strains lack the NcoI restriction site (nucleotide 110). This $\mathrm{NcoI}$ restriction site is present in all of the species included in the subcluster formed by the $\mathrm{N}_{2}$-fixing type DOR and type SAd isolates, Gluconacetobacter diazotrophicus, Gluconacetobacter liquefaciens and Gluconacetobacter sacchari. On the basis of the characteristics described above and the phenotypic features (Gram-negative aerobic bacteria, oxidation of ethanol to acetic acid, oxidation of acetate and lactate to $\mathrm{CO}_{2}$ and water), it can be concluded that the $\mathrm{N}_{2}$-fixing type DOR and type SAd isolates belong to the family Acetobacteraceae.

Over-oxidation of ethanol, first to acetic acid and then further to $\mathrm{CO}_{2}$ and water, has been considered historically to be a fundamental phenotypic characteristic 
of the genus Acetobacter (De Ley et al., 1984b; Swings, 1992) and it differentiates the genus from Gluconobacter (members of which are incapable of overoxidizing ethanol). Members of the genus Acidomonas, as proposed by Yamada et al. (1997), can be distinguished phenotypically from closely related genera by their ability to grow on methanol. As type DOR and type SAd isolates were able to over-oxidize ethanol but did not show methylotrophic growth, these $\mathrm{N}_{2}$ fixing bacteria can be classified as belonging to the genus Acetobacter according to Swings (1992). Otherwise, they might be assigned to the genus Gluconacetobacter, according to the proposal of Yamada et al. (1997).

A genetic distance greater than 0.5 in MLEE analysis has been used as a criterion to suggest species limits (Musser et al., 1987; Selander et al., 1985). On this basis, the MLEE results strongly support the notion that the type DOR and type SAd isolates could represent two novel $\mathrm{N}_{2}$-fixing species within the family of acetic acid bacteria. The results of ARDRA support the notion that the type DOR and type SAd isolates represent two novel $\mathrm{N}_{2}$-fixing species within the family Acetobacteraceae, since they can be clearly differentiated from the closely related species Gluconacetobacter diazotrophicus and Gluconacetobacter liquefaciens.

Although the limitations of $16 \mathrm{~S}$ rRNA sequencing for the differentiation of closely related species have been documented (Fox et al., 1992), it is suggested that $97 \%$ is the threshold 16S rRNA similarity level for the delineation of bacterial species (Stackebrandt \& Goebel, 1994). In addition, DNA-DNA reassociation levels below $70 \%$ are indicative of distinct species (Stackebrandt \& Goebel, 1994). Nevertheless, some bacteria that have shown 16S rRNA sequence similarities above $98 \%$ have been considered different species, since they had DNA-DNA reassociation levels lower than $50 \%$. For instance, the recent descriptions of Acetobacter pomorum and [Acetobacter] oboediens (Sokollek et al., 1998) and Gluconacetobacter sacchari (Franke et al., 1999) were based partially on 16S rDNA sequence similarity higher than 97.9 or $99.0 \%$ and levels of DNA-DNA reassociation below $50 \%$. In the present study, these considerations were consistent both with the 16S rRNA similarity levels and with the low levels of DNA relatedness exhibited within the Gluconacetobacter $\mathrm{N}_{2}$-fixing cluster. In this case, the $16 \mathrm{~S}$ rDNA sequence similarity among the type DOR and type SAd isolates and Gluconacetobacter diazotrophicus ranged from 98.3 to $99 \cdot 31 \%$ and DNA-DNA reassociation levels were never higher than $50 \%$, in spite of the fact that the hybridization conditions were not highly stringent. Comparison of the type DOR and type SAd isolates with other species of acetic acid bacteria produced reassociation values that did not exceed $21 \%$.

On the basis of the data obtained from biochemical and genomic analyses, we recommend that the $\mathrm{N}_{2}{ }^{-}$ fixing type DOR and type SAd isolates described herein should be assigned to two novel species of the family Acetobacteraceae. We propose the names Gluconacetobacter johannae for the type DOR isolates, strain CFN-Cf55 $5^{\mathrm{T}}$ being the type strain, and Gluconacetobacter azotocaptans for the type SAd isolates, $\mathrm{CFN}-\mathrm{Ca} 54^{\mathrm{T}}$ being the type strain.

\section{Description of Gluconacetobacter johannae sp. nov.}

Gluconacetobacter johannae (jo.han'nae. N.L. gen. n. johannae of Johanna, in honour of the Brazilian microbiologist Johanna Döbereiner, who isolated the first nitrogen-fixing species of the genus Gluconacetobacter and discovered several other nitrogenfixing bacteria).

Cells are straight rods with rounded ends, approximately $1.5-1.9 \mu \mathrm{m}$ long and $0.5-0.6 \mu \mathrm{m}$ wide, and occur singly, in pairs or in short chains. Motile by means of peritrichous flagella. Isolates are Gram-negative, oxidase-negative and catalase-positive. Colonies on potato agar with 5,10 or $15 \%$ cane sugar are light brown, but, after $10 \mathrm{~d}$, turn brownish and produce a brownish liquid pigment. Strains are aerobic and fix atmospheric nitrogen microaerophilically, even in the presence of $10 \mathrm{mM}$ nitrate. Nitrates are not reduced to nitrite, but isolates grow well with ammonium. Regardless of the presence of growth factors from yeast extract, very few carbon sources support growth. Strains grow and produce abundant acid on sucrose, $\mathrm{D}$-glucose and L-fructose and grow in $30 \% \mathrm{D}$-glucose or sucrose. Ethanol is oxidized to acetic acid and acetate and lactate are oxidized to $\mathrm{CO}_{2}$ and water. Isolates grow on 0.1 and $0.5 \%$ ethanol or $0.1 \%$ butanol, but not with 0.1 or $0.5 \%$ methanol. Growth occurs at $29^{\circ} \mathrm{C}$, but not at $37^{\circ} \mathrm{C}$, in LGI liquid medium at $\mathrm{pH} 4-7$. Growth occurs with 0.25 and $0.5 \%$ $\mathrm{NaCl}$, but not with $1.0 \% \mathrm{NaCl}$, in LGI liquid medium. Single amino acids cannot be used as sole sources of carbon and nitrogen. Characteristics that differentiate this species from other $\mathrm{N}_{2}$-fixing acetobacteria are shown in Table 2. This species can be differentiated from other $\mathrm{N}_{2}$-fixing acetobacteria by ARDRA patterns, in addition to DNA-DNA reassociation data, and by means of PCR analysis using specific primers. Strain CFN-Cf55 ${ }^{\mathrm{T}} \quad\left(=\mathrm{ATCC} 700987^{\mathrm{T}}=\right.$ DSM $13595^{\mathrm{T}}$ ) is the type strain and has a $\mathrm{G}+\mathrm{C}$ content of $57.96 \mathrm{~mol} \%$. This strain was recovered from the rhizospheres of coffee plants.

\section{Description of Gluconacetobacter azotocaptans sp. nov.}

Gluconacetobacter azotocaptans (a.zo.to.cap'tans. N.L. n. azotum nitrogen; L. part. adj. captans catching; N.L. adj. azotocaptans nitrogen-catching, referring to the ability to assimilate atmospheric nitrogen).

Cells are straight rods with rounded ends, approximately $1.6-2 \mu \mathrm{m}$ long and $0.5-0.6 \mu \mathrm{m}$ wide, and occur 
singly or in pairs. Motile by means of peritrichous flagella. Isolates are Gram-negative, catalase-positive and oxidase-negative. Growth occurs at $29^{\circ} \mathrm{C}$, but not at $37{ }^{\circ} \mathrm{C}$, in LGI liquid medium at $\mathrm{pH} 4-7$. Colonies on potato agar with 5,10 or $15 \%$ cane sugar are beige or very light-brownish, even after $10 \mathrm{~d}$. Strains are aerobic and fix atmospheric nitrogen microaerophilically, even in the presence of $10 \mathrm{mM}$ nitrate. Nitrates are not reduced to nitrite, but isolates grow well with ammonium. Regardless of the presence of growth factors from yeast extract, very few carbon sources support growth. Strains grow and produce abundant acid on sucrose, D-glucose and L-fructose and grow in $30 \%$ D-glucose or sucrose. Ethanol is oxidized to acetic acid and acetate and lactate are oxidized to $\mathrm{CO}_{2}$ and water. Isolates grow on $0 \cdot 1$ and $0.5 \%$ ethanol, but not with 0.1 or $0.5 \%$ methanol. Growth occurs with 0.25 and $0.5 \% \mathrm{NaCl}$, but not with $1.0 \% \mathrm{NaCl}$, in LGI liquid medium. Single amino acids cannot be used as sole sources of carbon and nitrogen. Characteristics that differentiate this species from other $\mathrm{N}_{2}$-fixing acetobacteria are shown in Table 2. This species can be differentiated from other $\mathrm{N}_{2}$-fixing acetobacteria by ARDRA patterns, in addition to DNA-DNA reassociation data, and by means of PCR analysis using specific primers. Strain CFN-Ca54 ${ }^{\mathrm{T}}$ (= ATCC $700988^{\mathrm{T}}=\mathrm{DSM} 13594^{\mathrm{T}}$ ) is the type strain and has a $\mathrm{G}+\mathrm{C}$ content of $64.01 \mathrm{~mol} \%$. This strain was recovered from the rhizospheres of coffee plants.

\section{ACKNOWLEDGEMENTS}

This work is dedicated to the memory of Dr Johanna Döbereiner (1924-2000). We are grateful to Dr Les Barran for reviewing the manuscript. We are indebted to Professor Hans G. Trüper for constructive etymological corrections of the new species names described in this paper. We gratefully acknowledge Professor W. Chen for $\mathrm{G}+\mathrm{C}$ content determinations. We thank M. A. Rogel for help with the nucleotide sequences of the $16 \mathrm{~S}$ rDNA gene and J. MartínezRomero for drawing Fig. 3. Partial financial support for this research was provided by grant UNAM-DGAPA IN209496.

\section{REFERENCES}

Boddey, R. M., Urquiaga, S., Reis, V. \& Döbereiner, J. (1991). Biological nitrogen fixation associated with sugar cane. Plant Soil 137, 111-117.

Bulygina, E. S., Gulikova, O. M., Dikanskaya, E. M., Netrusov, A. I., Tourova, T.P. \& Chumakov, K. M. (1992). Taxonomic studies of the genera Acidomonas, Acetobacter and Gluconobacter by $5 \mathrm{~S}$ ribosomal RNA sequencing. J Gen Microbiol $\mathbf{1 3 8}$, 2283-2286.

Caballero-Mellado, J. \& Martínez-Romero, E. (1994). Limited genetic diversity in the endophytic sugarcane bacterium Acetobacter diazotrophicus. Appl Environ Microbiol 60, 1532-1537.

Caballero-Mellado, J., Fuentes-Ramírez, L. E., Reis, V. M. \& Martínez-Romero, E. (1995). Genetic structure of Acetobacter diazotrophicus populations and identification of a new genetically distant group. Appl Environ Microbiol 61, 30083013.

Caballero-Mellado, J., Jiménez-Salgado, T., Tapia-Hernández, A.,
Wang, E. T., Martínez-Romero, E. \& Fuentes-Ramírez, L. E. (1999). Polyphasic taxonomy of nitrogen-fixing acetic bacteria isolated from the rhizosphere of coffee plants. In Highlights of Nitrogen Fixation Research, pp. 271-274. Edited by E. Martínez \& G. Hernández. New York: Kluwer/Plenum.

Cavalcante, V. A. \& Döbereiner, J. (1988). A new acid-tolerant nitrogen fixing bacterium associated with sugarcane. Plant Soil 108, 23-31.

De Ley, J., Gillis, M. \& Swings, J. (1984a). Family VI. Acetobacteraceae Gillis and De Ley 1980, 23 ${ }^{\mathrm{VP}}$. In Bergey's Manual of Systematic Bacteriology, vol. 1, pp. 267-268. Edited by N. R. Krieg \& J. G. Holt. Baltimore: Williams \& Wilkins.

De Ley, J., Swings, J. \& Gosselé, F. (1984b). Genus I. Acetobacter Beijerinck 1898, 215 . In Bergey's Manual of Systematic Bacteriology, vol. 1, pp. 268-274. Edited by N. R. Krieg \& J. G. Holt. Baltimore: Williams \& Wilkins.

Feng, D.-F. \& Doolittle, R. F. (1987). Progressive sequence alignment as a prerequisite to correct phylogenetic trees. $J \mathrm{Mol}$ Evol 25, 351-360.

Fox, G. E., Wisotzkey, J. D. \& Jurtshuk, P., Jr. (1992). How close is close: 16S rRNA sequence identity may not be sufficient to guarantee species identity. Int J Syst Bacteriol 42, 166-170.

Franke, I. H., Fegan, M., Hayward, C., Leonard, G., Stackebrandt, E. \& Sly, L. I. (1999). Description of Gluconacetobacter sacchari sp. nov., a new species of acetic acid bacterium isolated from the leaf sheath of sugar cane and from the pink sugar-cane mealy bug. Int J Syst Bacteriol 49, 1681-1693.

Fuentes-Ramírez, L. E., Jiménez-Salgado, T., Abarca-Ocampo, I. R. \& Caballero-Mellado, J. (1993). Acetobacter diazotrophicus, an indoleacetic acid producing bacterium isolated from sugarcane cultivars of Mexico. Plant Soil 154, 145-150.

Fuentes-Ramírez, L. E., Caballero-Mellado, J., Sepúlveda, J. \& Martínez-Romero, E. (1999). Colonization of sugarcane by Acetobacter diazotrophicus is inhibited by high $\mathrm{N}$-fertilization. FEMS Microbiol Ecol 29, 117-128.

Gillis, M., Kersters, K., Hoste, B., Janssens, D., Kroppenstedt, R. M., Stephan, M. P., Teixeira, K. R. S., Döbereiner, J. \& De Ley, J. (1989). Acetobacter diazotrophicus sp. nov., a nitrogen-fixing acetic acid bacterium associated with sugarcane. Int $J$ Syst Bacteriol 39, 361-364.

Jiménez-Salgado, T., Fuentes-Ramírez, L. E., Tapia-Hernández, A., Mascarúa-Esparza, M. A., Martínez-Romero, E. \& CaballeroMellado, J. (1997). Coffea arabica L., a new host plant for Acetobacter diazotrophicus, and isolation of other nitrogenfixing acetobacteria. Appl Environ Microbiol 63, 3676-3683.

Jukes, T. H. \& Cantor, C. R. (1969). Evolution of protein molecules. In Mammalian Protein Metabolism, vol. 3, pp. 21-132. Edited by H. N. Munro. New York: Academic Press.

Mascarúa-Esparza, M. A., Villa-González, R. \& Caballero-Mellado, J. (1988). Acetylene reduction activity and indoleacetic acid production by Azospirillum isolates from cactaceous plants. Plant Soil 106, 91-95.

Musser, J. M., Bemis, D. A., Ishikawa, H. \& Selander, R. K. (1987). Clonal diversity and host distribution in Bordetella bronchiseptica. J Bacteriol 169, 2793-2803.

Page, R. D. M. (1996). TREEVIEW: an application to display phylogenetic trees on personal computers. Comput Appl Biosci 12, 357-358.

Selander, R. K., McKinney, R. M., Whittam, T. S., Bibb, W. F., Brenner, D. J., Nolte, F. S. \& Pattison, P. E. (1985). Genetic structure of populations of Legionella pneumophila. J Bacteriol 163, 1021-1037. 
Selander, R. K., Caugant, D. A., Ochman, H., Musser, J. M., Gilmour, M. N. \& Whittam, T. S. (1986). Methods of multilocus enzyme electrophoresis for bacterial population genetics and systematics. Appl Environ Microbiol 51, 873-884.

Sievers, M., Ludwig, W. \& Teuber, M. (1994). Revival of the species Acetobacter methanolicus (ex Uhlig et al. 1986) nom. rev. Syst Appl Microbiol 17, 352-354.

Sokollek, S. J., Hertel, C. \& Hammes, W. P. (1998). Description of Acetobacter oboediens sp. nov. and Acetobacter pomorum sp. nov., two new species isolated from industrial vinegar fermentations. Int J Syst Bacteriol 48, 935-940.

Stackebrandt, E. \& Goebel, B. M. (1994). Taxonomic note: a place for DNA-DNA reassociation and 16S rRNA sequence analysis in the present species definition in bacteriology. Int $J$ Syst Bacteriol 44, 846-849.

Swings, J. (1992). The genera Acetobacter and Gluconobacter. In The Prokaryotes: a Handbook on the Biology of BacteriaEcophysiology, Isolation, Identification, Applications, vol. 3, pp. 2268-2286. Edited by A. Balows, H. G. Trüper, M. Dworkin, W. Harder \& K.-H. Schleifer. New York: Springer.

Thompson, J. D., Higgins, D. G. \& Gibson, T. J. (1994). CLUSTAL $\mathrm{W}$ : improving the sensitivity of progressive multiple sequence alignment through sequence weighting, position-specific gap penalties and weight matrix choice. Nucleic Acids Res 22, $4673-4680$.
Urakami, T., Tamaoka, J., Suzuki, K. \& Komagata, K. (1989). Acidomonas gen. nov., incorporating Acetobacter methanolicus as Acidomonas methanolica comb. nov. Int $J$ Syst Bacteriol 39, $50-55$.

Weisburg, W. G., Barns, S. M., Pelletier, D. A. \& Lane, D. J. (1991). $16 \mathrm{~S}$ ribosomal DNA amplification for phylogenetic study. $J$ Bacteriol 173, 697-703.

Yamada, Y. (2000). Transfer of Acetobacter oboediens Sokollek et al. 1998 and Acetobacter intermedius Boesch et al. 1998 to the genus Gluconacetobacter as Gluconacetobacter oboediens comb. nov. and Gluconacetobacter intermedius comb. nov. Int J Syst Evol Microbiol 50, 2225-2227.

Yamada, Y. \& Kondo, K. (1984). Gluconoacetobacter, a new subgenus comprising the acetate-oxidizing acetic acid bacteria with ubiquinone-10 in the genus Acetobacter. J Gen Appl Microbiol 30, 297-303.

Yamada, Y., Hoshino, K. \& Ishikawa, T. (1997). The phylogeny of acetic acid bacteria based on the partial sequences of $16 \mathrm{~S}$ ribosomal RNA: the elevation of the subgenus Gluconoacetobacter to the generic level. Biosci Biotechnol Biochem 61, 1244-1251.

Yamada, Y., Hoshino, K. \& Ishikawa, T. (1998). Gluconacetobacter corrig. (Gluconoacetobacter [sic]). In Validation of Publication of New Names and New Combinations Previously Effectively Published Outside the IJSB, List No. 64. Int J Syst Bacteriol 48, 327-328. 